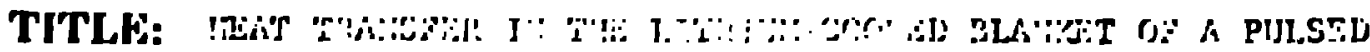
FU:istia IR:ACrol?

AUTHOR(S): r. F. . Cort ane' R. ^. Kruluonskt SUBMITTED TO: 6th Internationel lleat Transfer Conference,
Toronto, Ontar 10, Canada, August 7-11, 1978

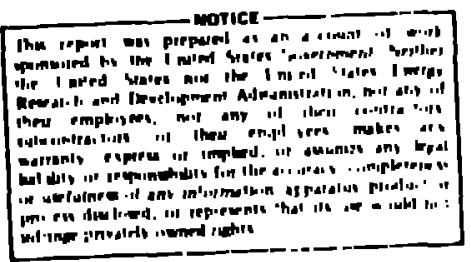

By acceptance of this article for publtcation. the publishor recosnlzen the Government's (llcenne) rights In any copyrifht and the Covernment and It authorlzed representativen have unreatricted right to reproduce In whole or In part onld artlele under any copyrisht cecured by the publinher.

The I an Alumow Selentific Iaboratory requests that the publiwher identify this article as work performed under the auspicen of the USEKDA.

An Alfirmative Action/Equal Opportunity Employer

Finrm Nio. Ait:

Si. No. 2(i; 40

st.
UNITED S'TATFS

FiNBKLYY RESFARCH AND

DEVWI.OPMFNT ADMINISTRATIOX

CWITHACT W-7405-FNG, 36 
HEAT TRAHSFEK IA THF. I.ITHIIM-C(X)I.F:D HIANKF.T OF A PULSED FUSIO: RIAC:I'IH

\section{E. Cort}

\section{R. A. Krakounk I}

LoB Alamon Scient If Loboriatory, UnIversity of Califurnia, Los Alumns, Ner Mexico B7545 U. S. A.

\section{ABSTPACT}

The transicint tomperature djgtribution In the Ithlua-cooled blanket of $n$ pulsed fution reictor has been calculnted using if [Inttu-tudment hi iltconduction conputer proprilm. An auxtliary progran uas ueed to predict tho coolant trinslent velocity in a network of parallel and serfos flut pasisapes with conntant driving prcessure and verying mapnet le rleld. The coolant velocity wis riliulated by a Runge-Kutta numerical integriation of the conscrvation equat Ions.

The litilum conlant was pirt of the fintes-element heat-cenduction mesh with the velucity terma Included In the tolal matrIx. The mitrlx was solved Iopliclely at cach time htep for the nodil point temperalures. Slup fluw was assumed ln the coolnnt pasoges and the Bousis Inewn annlugy wisi usied co calculate turbulent hent trinefer when the magnet ic field was lot present.

\section{WOMTENCI.ATURF:}

D - engneldc rjeld, Tcula

k - Boltzmann conatant

n = Ion denaity

$R=$ hydraulic radius of flow chanilels

De - Reynolda number, uR/v

T - terperature

u veloctiy parallel to centerline

\section{Greek Lettere}

B - ratio of planan kinctic prengure to confining enetic preasure - $2 \mathrm{nkT} /\left(\mathrm{B}^{2} / 2 \mu_{0}\right)$

AP - total driving prewbure for lithium flou

$A$ - eddy thermal coilductivity

H. $=4 \pi \times 10^{-7} \mathrm{H} / \mathrm{m}$

E- eddy dynanic vincosity

v liner tic viscoaity

\section{IMTROEUCTION}

Amotng that there will be algnilicant advances in the phyaics of plapme confincment, the potential for controlled thermonuclear fuaton for cconoalc power production is being assesued. As part of the overall affort, conceptual but cooprehenstve

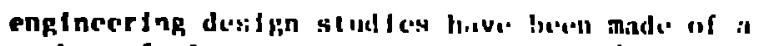

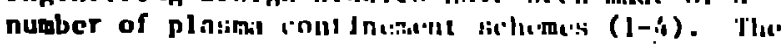

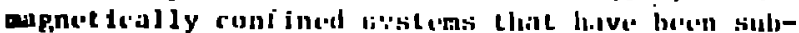

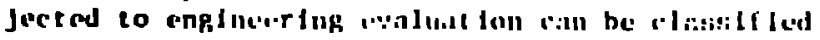
ae atsndy atile (1), quist-steady state (2), and pul hed (3). The mothernat dral model lng af neutrontc/heid -transfer/structurial aspects of the

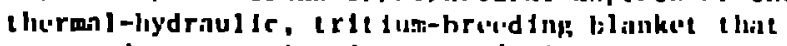

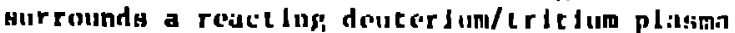

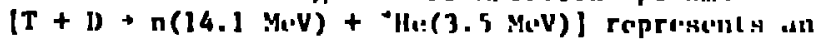
Intepral part ( $\underline{5}, \underline{6})$ of the overall technological agechanint (T) provided ay these fusinn reiaterr atudlca. Parllcular allent fin must he pjven ta all heat-trinufur ispei:Ls of pulsted tislon roulcupta. Althouph the result s of liciat-tranefer/

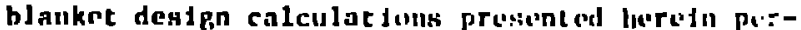
tatn epecifically zo the coroldal keference IheliaPlnch Reactor (KIPR) (4), Lhese re:iulle are prillerally applicable, ulth sume moditication, to othel pulsed mignetfeally-conf inced fusion power roncup!s. The blanket alructure (or "firat wall") that directly faces the hot (10 to $30 \mathrm{keV}$ ) ' reactink. plasma reprewente a particularly crucial heistirangier/thermal-stress problem, whlch has beun treated in dolall clnewhere (8). This paper focuses primartly on the thernil/hydraulic rueponse of the entire liquid-11thiur-cooled blankst.

The RTPR w11l operate as a high- $\beta$ stellerntor (4) where the plasna to heated compressionally by 1 rengetic field that does not penetrate the plasin during the confincwent time. The RTPR wust operate in a pulaed mode with thermonuclear burn tiric of 0.1 to $0.4 \mathrm{~s}$. Importane paranetera associaled wth the RTPR pulned powcr cycle are thoun echenatically In FIg. 1. The physical relationahip between the plasma, blanket, and mignetic coll. 1. ohown In Fig. 2. The puleed rusion reactor is composed of a ecrien of these - 2-mlong modules arranged end-to-cind. It should be eaphasized that the segmented blanket otructure cerven as a manetic flux concentrator on the $1 \mathrm{~m}$ plosion-heating time cale ( -1 He), and is divided into regions that are omall enough to ainiolec eddy current loases on the adinbatic compreasion tin ecale (-30 ma). The blanket Ia otherwlse alectrically and mechanically decoupled from the menetic colle and asociated electrical clrcultry.

Each cylindrical nodule of the gegmented blanket 1. divided Inco 100 azlmuthis aectors show In core detall in Fib. 3. Each scgment represents an

\footnotetext{
1 l keV $-12.5(10) * k$.
} 
Independent fJow systom. The scigments are :ishd I-

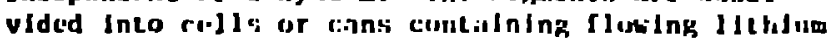

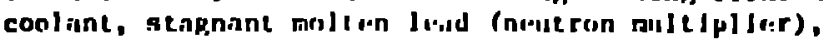

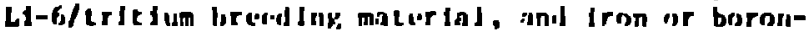
carbide ahicloling. (Flg. 3). Alumino (electrical)

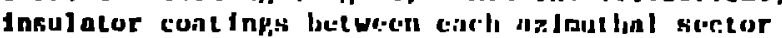
are algo Included, and the structuril materlal is 1-a-thick Nb-1\%r alluy. If licer methods of fobrtanton have been considered as illecrnat Ive?, lut only

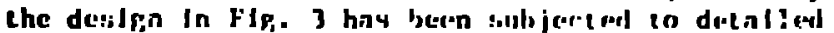

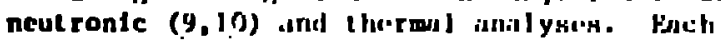
blankct schoueni Is fabrteated from a flat shrect

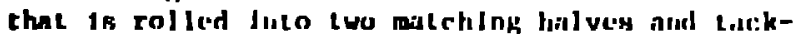

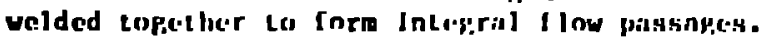
This type of ronts trut:Llon is romonly utied for

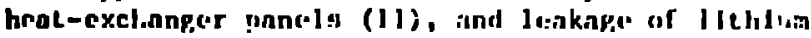

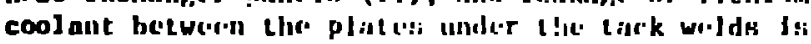
not detrlinenenl to blinket pe-rformillice. Hexnyunal

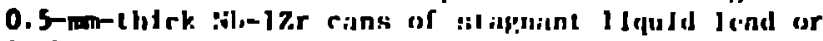

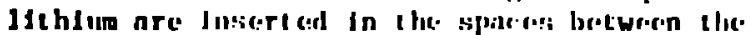

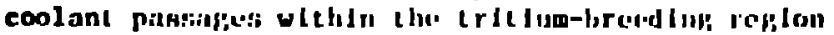

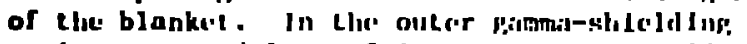
region uncamned lopis of Iron or lxornn-tarulde are Inaerted. Figure 3 has been : Implif Juel to silisw only nome tyndeal blankmL lifycru; seven coulint ducta are actually considered neceshary.

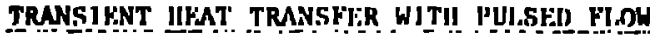

The burn cyeje paramelers depleted In Flo. 1 wer: used wilh ons-dimrensinnil (cylintriral) neitronlc calculations to provide Lho limo-space dependence of the neutron und gammariay power denstlie:i. Flgure 4 is a concedimensional representilt lon of the nout ronlc/heat-trahifor cnjeulat lonal modol and Table I suminetres the key purimeters used in the b]ankel heal-etrinifir cnlculitjolis. Ber:nuse of the puled mngnelic ficlas, liquid-lithlum coolant flow w11 alno be tire dependent during the plasisa burn and quench $\mathrm{Htages,}$ and the tinc resolition of the coolant flow, therclore, reprement:t an eshentinl fenture of the blanket heat-transfur calculation.

Hguec 5 given the liquid-illhtum flow circutt for the blanket configuration depteted In Fig. 3 . Bucause of the large pressure drop creilted by the agnetic firld during the burn, the lithiun coolant flow virtualiy ceases during this period. Ihe transient and ateady-atate flou rates are calculated for each coolant leg depicted in FIg. 5. The

TABLE 1. Parameters used In Blanket HentTransier Colculations

Intelal Blanket Temper atura Coolant Inlet Temperature

Duty Cycle

Rise Time of Compreasion Ficld

Compreafon Ficld, Flut-top Time

Plasara Cooling Time

Iplosion Heating Mngnetic Field

Maxtmun Compreaston Ftald

Quencli FluJu

Total Neutron and Gawmi Eneray

Brensetrahluisg Encray

Plaura Internal Enorgy. End of Burn

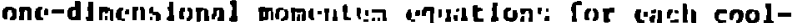

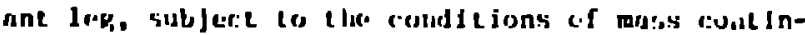
uley and pretiurce balahele. are lased to desertbr.

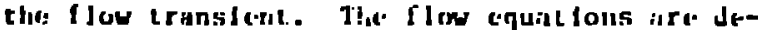
rJved for $n$ sliphlity different po-ometry in Ref. (12) by uke of the following slmplifyitug aיiumptJons: 1. Incompressiblc. rluid, 2. rnnstant

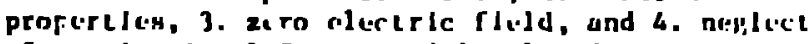
of gravltall Jonal forrec:; and Jucial laod gconcelry rfforty at the manifolds. Based ron a $1 \mathrm{Jthlum}$ nound spered of $4.2 \mathrm{~km} / \mathrm{i}$, the chericterlstic trisvel time for a pressiure wive to rench the and of the. 2-m modula if ..12 of the lime for the lduld to comer to rest. Therrefurc, the flow cransicnt ly "gluw" uJth refiprel to the wive ve-locity ind Inet-

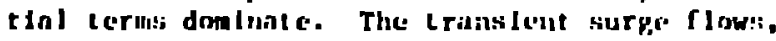

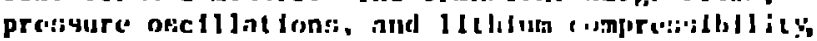
thercefore, are noplecterl for gurpuses of datermlaJipy hent tranifer in the blanket.

Tho nnnd Inentilonil momentum equat tont; (12) Sor

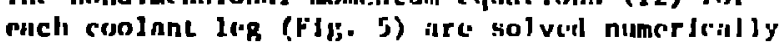

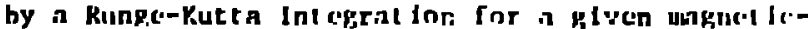
fleld waveform on pive the jlus velocity. This'

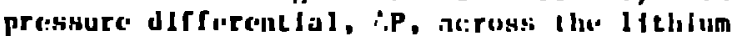
Inlet-out]ct seasured al a relerence poln! nut:alter the mapnctic field (FIg- 5) Is lirid i Ixed. In this way the rlow condicton withlin the mapnetli. fleld is decoupled from the external piplng alil murge tanks. The pressure drop result ing from flow acrose the pulurd misynrelc: Ffold lines !: taken Into accoum only for the Inlot and cxit lege; Ideally, the Ilartmann number ls noro for thes other coulant leg, with flow parillal to tho mog:net Jr rield.

An Importint objective of the blnnket degtun Is 10 minimize the lithlum flow rate and punptng power. Two npproximate IImile huve heren citablished for the lithlum flow. The Inusr $11 \mathrm{mlt}$ correspondi to the case where the flow barely achleves stendy Htate at the end of a 5-4 cycle time for a piven flow peometry and minnet le fleld. The upper limit It wet by the fJow above which no wlynifleant improvonent in hlanket lecmperatures occurs isiciluse the rate of heat transfor $1 \mathrm{~s} 1 \mathrm{lmlled}$ by condustion out of the solid (or singnant liquid) reglons. parnoctrle studles ahowed that theme 1 Imits cover a rather narrow range 1 rom $0.0035 \mathrm{~m}^{3} / \mathrm{s}$ per ecpment at $\Delta P=5.1 \mathrm{kPa}$ to $0.012 .5 \mathrm{~m} / \mathrm{s} \mathrm{per}$ segment nt 51 $\mathrm{kPa}$. The correeponding Idenl pumping power ner neter of length var 1 es from $0.9 \mathrm{kHe}$ to $30 \mathrm{kWe}$ at peak flow for the 100 megmonts in n module. The blanket wil theoreticaliy operate at nny interandiate flou provided the cradeoffa in pumping power, temperatures, and temperalure cycle are acceptable.

Tho flow velocitice in the inlet lag are shoun in PJB. 6 for a range of $\Lambda P$ valuce and the mngnetic field time history indlented. The high-flou cane (AP = 51 kPa) wan chosen na a reforence cnHe because it resulte in the minimun temperatures and thoral otrese in the blanket. Th: flow velocttes In the seven 2-m-long coulant legy within the blanket follou a nimilar time hletory to that given in PIg. 6, but differ In magnitude because of differences in rlow area. 


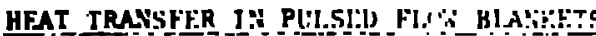

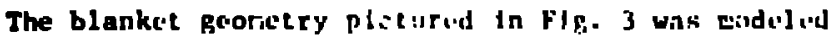

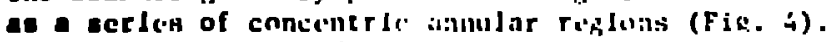
The two-dimensional $(r, z)$ lia-iat-irinsicet muJel Ineluded convective torms vhere apiro,riats. but by

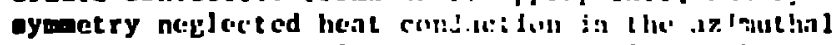
direction. A general furju'se ! Inita-tlomint hedilconduction program, AYF.R (1.1), wis da.ic!. The pro-

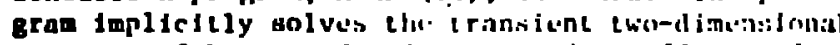
equation of lieal conduct Ion, Int luding efforts oi Inplane anlent rople conduct fulty, tarce-dimuilitonil valncley distribution, and interiact the rasl condacl resighance.

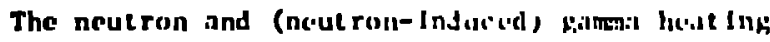
varles ncros! the blanket ly more tliln an nr.ter of

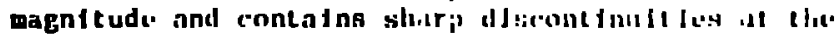
coolune chamels (10). During the Lher:ıonueledr

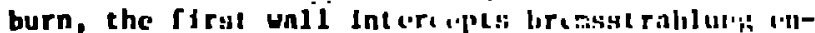
ergy flux, Fla. 1. After the 0.4 s of Ihermuneloar burn, the plnema internal energy to removed by a

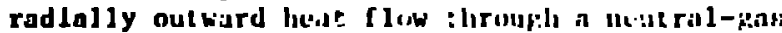

layer to the [Irat wall $(12, \sqrt{4})$. Aa Injortant

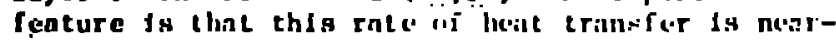
ly constant uth Lime (12,. Ilu total aneriy depasteed In the blinket iruta each of the

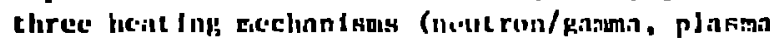
brcmsstralilung, and plasmil dunp) is susinoriged in Tablo 1.

The lithium conlant is Inclided in the finile-

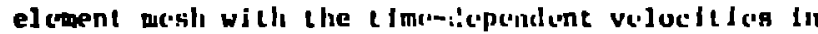
cach leg spectficel. Tis: voluctity ts tiken to be unfform in ench coojint l(p (sluj: fliw), with heat transfor from the wall sccurtill: by molocular conduction , 'ly in the presence of mapinetis fields or when the flow to laminar. W'lien the mibinclis field te nera and the [low d:; turiulent (Ke, 2000), an eddy conductivity in used to cnforce the laminar f: rmulntion (Boustinusq allijogy) (15) on the wall heat flux.

The eddy thermal conductivity, $\Lambda$, was found by combjning Koliscinow and Cohen's; (16; expreselon for tha turbulent Prandtl number with Spalding's (17) "Iaw of the wall" for the eddy drnande viscoslty, 5 . Throuph the use of the hlauslus (15) rilation for the wall friction, n representilive value for $A$ was found that to baned on the average velocity. Although $C$ and $\Lambda$ vary with posit in In the peneral case, bolutinns for the temperature gridiente in pipe flow shou (18) that $\Lambda$ is relutively constant for liquid metnla. The reriatance to hent flow to not found in the laminar mublayer or in the buffer layers, as Is the case wilh other flulda, but $f_{p}$ mre evenly dintributed throughont the crosa secton. The determination of $E$ from an Inner lay or "1av of tho ua11" (17) any be questioned, alnce the outer layer, or "lau of the wake" appeste to be core applicable. Tlie derlston to use the "Jins of the vali" was arbitrary, und wat influenced by factore of conventence and consurval lom (predfeting lowe heat-tranaler rateg). A connervit lve value for $A$ 1s dealrable becaune the turbulent eddies vil probably be danped by the magnetic fleld. The pripelpal advintigh, In usinp. the colily conduct Ivity Instend of a lyun-type rolal lumship (19) fur con-

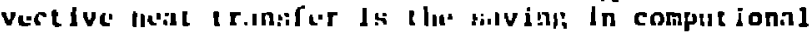
effort wilh the fintecedinicht mesh,

Thermal conticet reqfetinc, hetwein the? metal cans

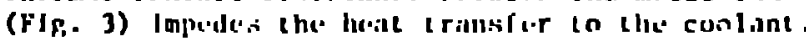

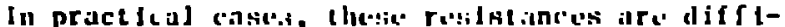

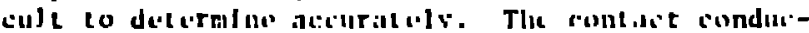

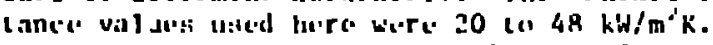
Thene are hlph values lor molall le silfiaces in a

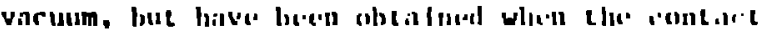

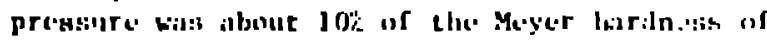
the metal (?0). Although mure delatlad blantrot

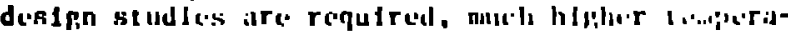

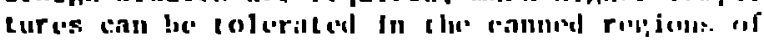
the blankel thin were found uslily thts istiumpt for:.

Therce Is a 20-mm Jayir of alumInal clertedral Insiu-

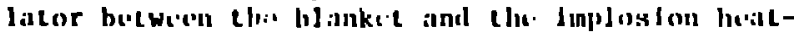

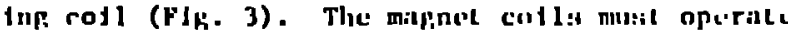

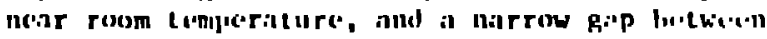
thy cotl and flesulitur would illor liminitr iluw of

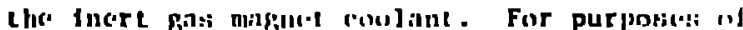

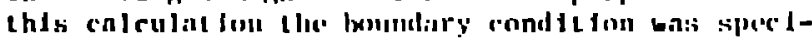
flud ab locilum at $300 \mathrm{k}$ In liminar flisw.

\section{RESTULIST}

Two domndns of hlanket heat (ran!sfor are Jelunt iflod: (1) Lhe transient start-up perfind when the the-averapad temperature of eich blinket reiplon appronchue a coustant vnlur; (.) tho steidy-ilit.. reglme whore the tempernture of eiteh reginn oicillr.ces alsout the ctmo-iveriphed vilues. Thil iranflent glart up heging from an inltJal limpir.!luru inat is detcrmined by the dehice of blinket imil zoolant prehcating and laste for 20 to 30 5-s power cycles (FJga. 1 and 5 ). The mant acvorc thermal tranifuts are of the first wall (8).

Figure 7 gives the tine dependence of Lemperaturet In three regions of the blanket dur lng the tranolent atart-up pertod. The coolant mixed-muill cenperature riac during thi atirt up gradualiy tncreancs fron zero tu a atable value a[ler 20 5cycles. The reference cnse $(\Lambda P=51 \mathrm{kl}$ a) his a lou alxed-mean coolint temperalure rine (miximum $57 \mathrm{~K}$ to mintmum $11 \mathrm{~K}$ at and of the duty cycle), which could affect the purformance of the Intermedate heat exchanger. The tompurature rlas for tho lowrr ( $\left.\Lambda)^{\prime}=5.1 \mathrm{kPa}\right)$ [ $1 \mathrm{nW}$ is more thall adsquate from this viawpoint (maxjmun $-140 \mathrm{~K}$ to mintrum $117 \mathrm{~K}$ at end of the duly cycle). Pigure 8 shows the typical uteady-atate ridinl Lemporature profile through the blankel at the etart (and end) of a duty cycle and at the end of the $\Gamma$ lasmil dump when maximum [1rat-wa]l tmperatures ire renched. Tenperaturen are nlso piven for the case of the lower coulant rlow $(\Delta P=5.1 \mathrm{kPa})$. An Indicatlan of the nxial temperature varintion if plven in F1g. 8 by depleting the radial temperiture profllo

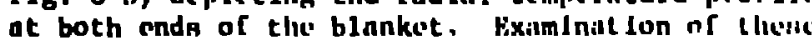
and similar temporaturc plota loads lo these obcervations: 
- The IJrst lead raylon axpericenress the hIplitest temperacures In thi blaniel cexcept nt the and of the plism dump wien the IIrst will riscs to aboul $270 \mathrm{~K}$ above thr cuoluit inlet $\mathrm{t}$ cmperature.

- Teaperatures gencrally decrinse wlth radius acrosh the blanlact vith 50 lo $100 \mathrm{~K}$ compurature. oectllnt lons occurting, ulthin the stagnant liquld regions (no conveclion asrumud).

- The hel Ium coolunt in the collg; nt the outcr dlanteler of the blankel cilusc-! n large (..150 K) gradiont In thr alumina Insilialor al Lhe oulor radiuli, but no istrnlfleant trwperature differencef orcur in thr. bulk of thr' blinkel.

- Temperntur'!; In the nut er portion of thr blanket rcmuln redat Ivaly constant throuphout the burn at -50 $x$ above: the reforener l cmpecrinture.

- The grent det axlal temperacurc diffe-rencef nceur In the firat wall at the end of the plasimil dump.

For the corresponding cempcracurc prof lles with the lower (AP - $5.1 \mathrm{kPa!} \mathrm{Ilthfum} \mathrm{fluw,} \mathrm{thic} \mathrm{Nimc} \mathrm{genciril}$ concjuslons npply crecpt that the temperature exrremes are up in $55 \%$ preater. Although maxifiun cemperatures at tho flrst wll are greilter than

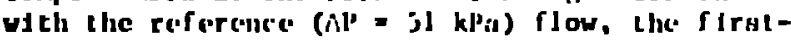
uall temperature chinge: durlng a burn cycle shows no etrung drpendenc:e on the coojnit [ Jow ralce.

\section{SUMpQMRY}

For the duty cycle confidured al blanket regtons reuch maxlmum lomperitare!s at the end r.f the therwonucl car burn. Thege max Imn are, respectively, $240 \mathrm{~K}, 160 \mathrm{~K}, 120 \mathrm{~K}$, and $80 \mathrm{~K}$ ahove the coolnit inlet cenpernture for lead, I,1-6, Iron, and bornncarbids. The miximum axlal terpernture difference In the blankel $1 \mathrm{H} 160 \mathrm{~K}$ and nccurs in the firet uall at the end of the plasmn dump. Parametrje atudies thit viry hoth A.P and the geonetry (aize, postetoll, number) of the J Jhium coolant clumnele u11 blow that boch lncal and averape Lemperature variations In both spnce and cime can be mo lesa pronounced than those computed for the extreme cnses shown In $\mathrm{rig}$. B.

\section{ACKNOAIFIDGMENTS}

The authora would like to thank S. A. H. Gerat1 for providing the neutron and gamen heating digtributlous and R. I. Miller for $l$ ic platwn energy and hreastrahlung flux. Thls we was performed under the auapices of the U. S. ERDA.

\section{RFFERFNCF.S}

1. Molr, R. H. et nl., MJrror Reultor Studjus, Procecdings of chic Sixth Internatinnal Coujerence on riasm Physirg and Controlled sucletir Fufion Resenteh, Berchtesgaden, FRG, pilper $(1 / 2)$, October 6-13, 1976

2. Scacey, H. M., Bnker, C. C., and Hoberts, M. Tokamak Pexperimrnen] Pourer Heictor, paper (I/3-2), JbId.

3. Krakowskt, R. A., el al., Pure-Fuslon and Fuslon-rission Applitritions of Hlefl Density I.Incist Conflnenient systens, paper (I/f), Jbid.

4. Krakewski, R. H., QuInn. W. H., Klbs, F. L. and Thomas, K. W., Nur:1. Eng. InLernatlonnl, 45. February, 1977.

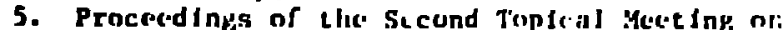

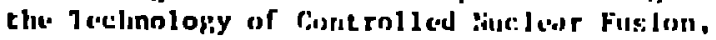
CONF-760935-1'4, ?., Chapler 5, 371-53B, Septcisber, 1976.

6. Mtsra, B., Stevins, Il. C., and Maruni, V. A. Thermal liydrisulfe and Pouer Cycle. Annlysis; if Liquid LIthfum Blanket Desigha, Proccedlngt ": the 1977 Mat Jonil Heal Transfer Confurunce. Salt Lake Cily, Ntah, Aupusil 15-17, 1977.

7. rowell, J. R., Fillo, J. A., TulnIng, B. C., and borning, J. J. (eds.), l'roccecedtage ut Li: Magnet lc Fusion tinergy Blinko:t and Shfeldlu;

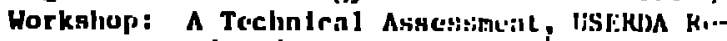
pore F'RIJA-76/117/1, Aughist, 1975.

B. lirakowgkt, R. A., Ingenoun, K. l.., and Cort, G. E., Nucl. Techrici., 34, P. 217-241, 1977.

9. Stmons, F. I.,. Dudxiak, b. J., and Geritl, S. A. W., Reference Thetn-PIne'in Reinctor (RITR) Neutronir Dealpu Senflelvity Analyste by Preturbation Throry, LslikDA Repurt I A-6572-MS, Apr 11, 1976.

10. Gricbll, S. A. W., privace rommunlcation. I.osi Alame Scient If Ic Laboricory, 1977.

11. ASILARF, llandbook and Pruduct DIrut:tory, Amcr Lcan Socjety of lleating, RefrJgivition and AlrConditionlng FngJuegre, Inc., Neu Yorix, 1974.

12. Krakow日k1, R. A., R1be, F. I.., Coultas, I'. A., and llatch, A. I. An Fngincoring Iesten of is Roference Theta-Pinch Redetor (RTPR), Lisfilds Report LA-5336/ANJ,-PD13, Merch, 1974.

13. I,nuton, R. G. The AYER deal Conduct ton Computer Program, USERUA Report LA-5613-MS, May 1974.

14. Gryczkousk1, G. R., and 011phant, T. A., Nucl. Fusion 16, 2,263, 1976.

15. Bekert, E. R. G., Drake, R. M., Jr., Heat and Mnne Tranafer, Mefraw-H111, 1959.

16. White, F. H., Vjecous Fluid Flou, lat Edition, P. 560, MeGray ll111, 1974.

17. SpaldIng, D. B., J. App1. Mech. 28, 455, 1961.

18. MnrtIne111, R. C., Trangactions ASME 69, 947 (1947).

19. Lyon, R. N., Liquid Metals Handbook, NaVExos P-733 (Rov), 1952.

20. Fried, E., and Coste1lo, F. A., ARS Journa 32. $237,1962$. 


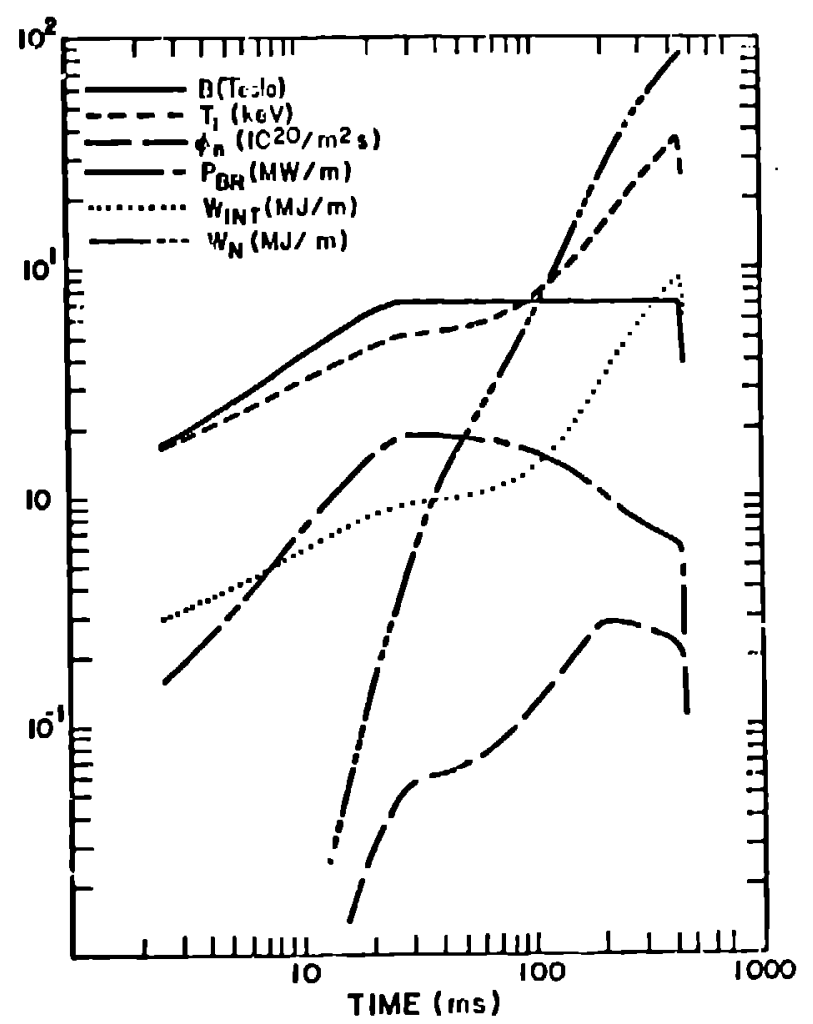

Flg. I RTPR Tfme-dependent Paraneters: magnct le fleld, - ; ton Lemperature, - - - ; neutron flux at flrst will. _... ; bremsstrahlung power, - _ _ ; platma lnternil energy, .... ; and ne.ut ron energy, -..--

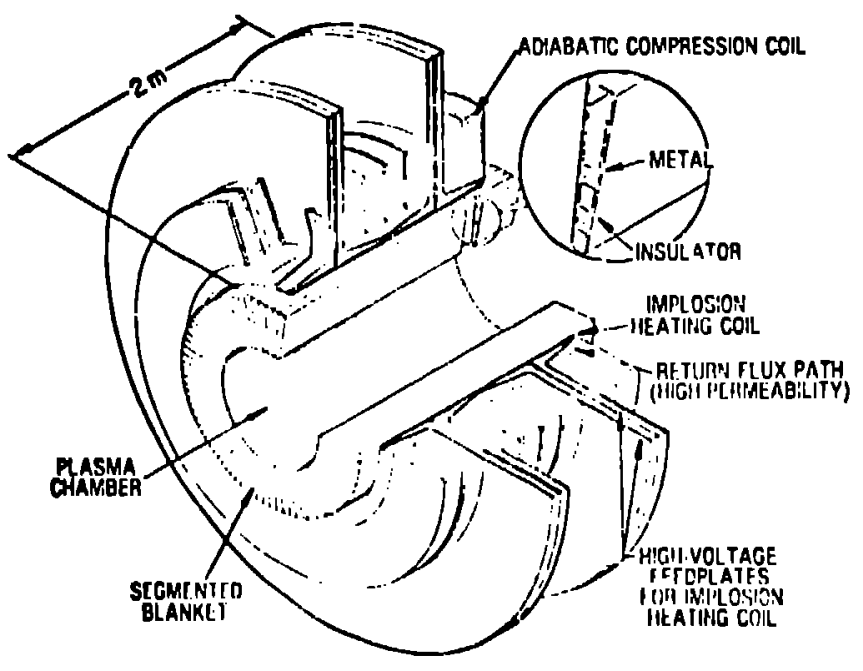

F18. 2 Arrangement of blanket, milgnet ic colla, and plasmi in a pulsed fuston reactor module.

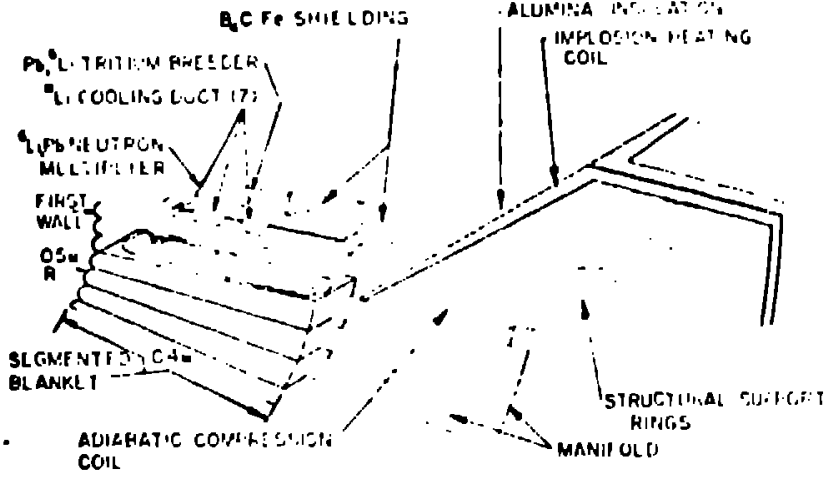

F1g. 3 Blishket si ru:Luru and llow millifold.

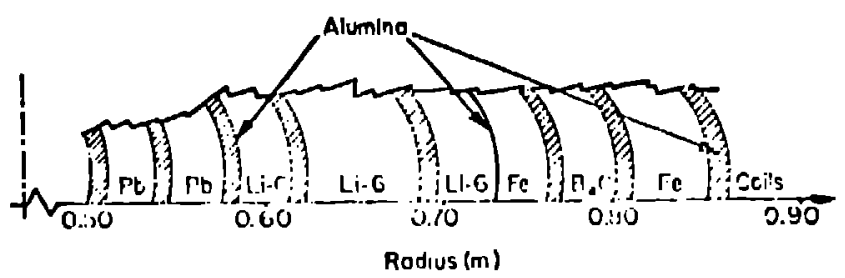

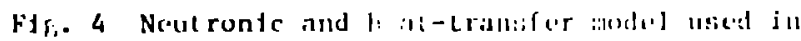
thesto cillioliltionli.

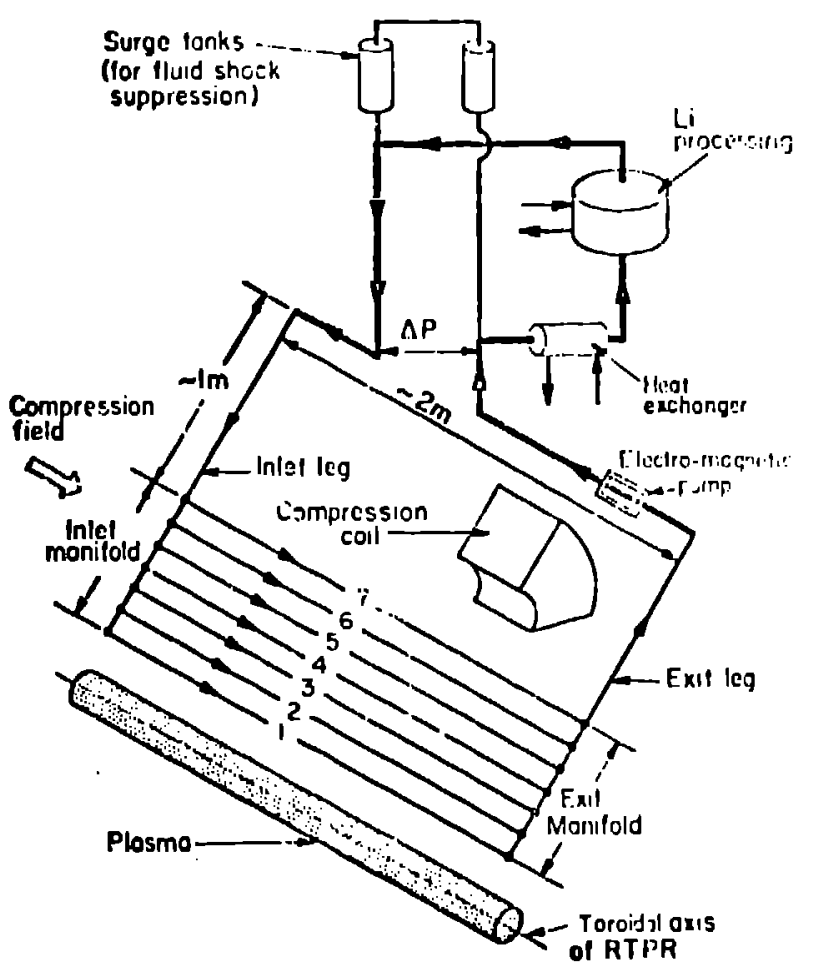

F18. 5 Flow diagram uned to describe the tranalent and otcady-state flow conditions in a 2-m reactor module. 


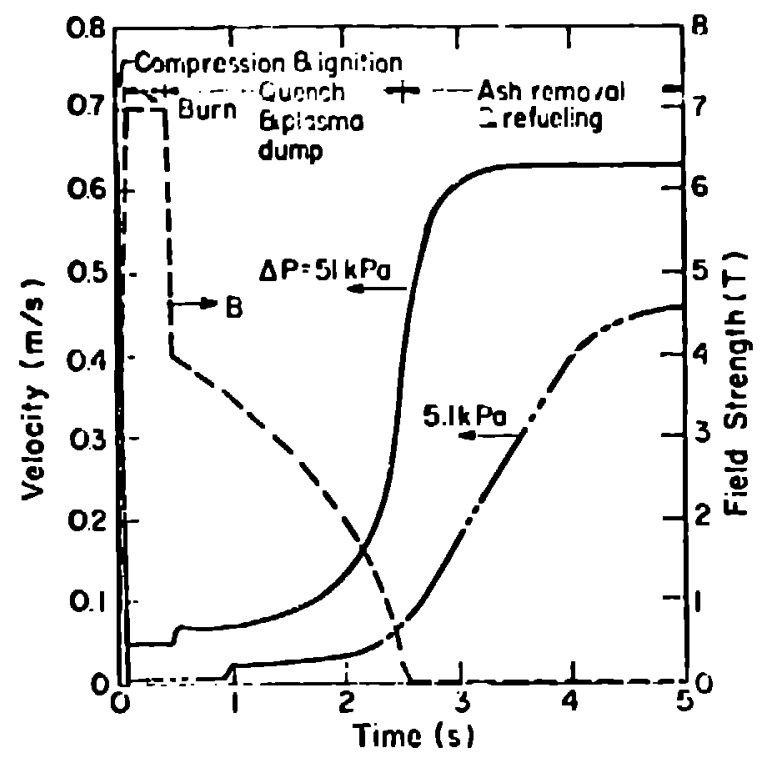

Fig. 6 Magncise fleld and lithlum flow velocity in inlel (and cxit) leg to blankel ucigmint.

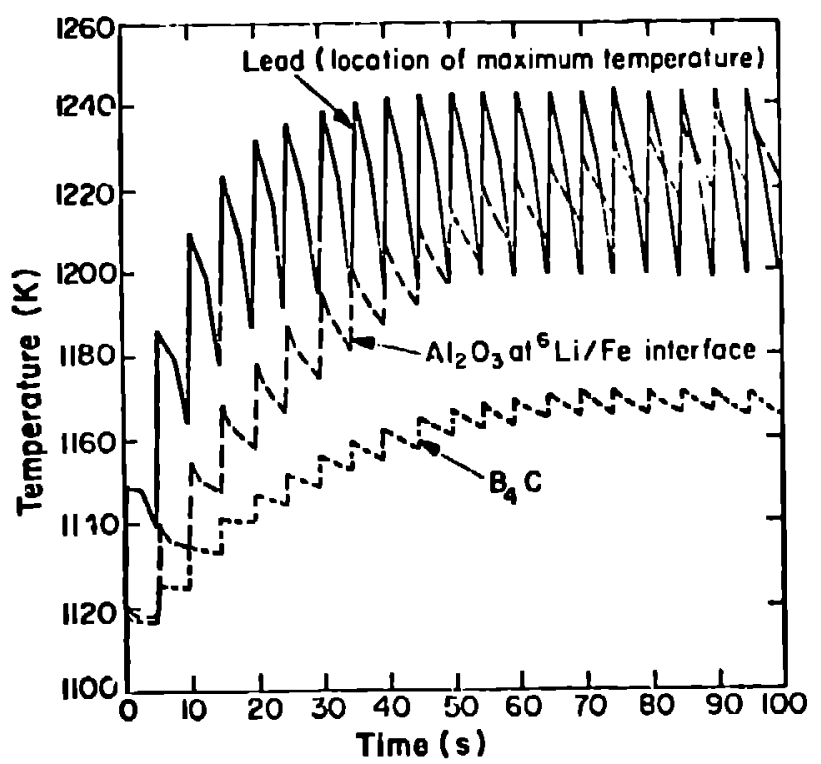

F1B. 7 Time dependence of temperatures at selected points in the blanket during atart up.

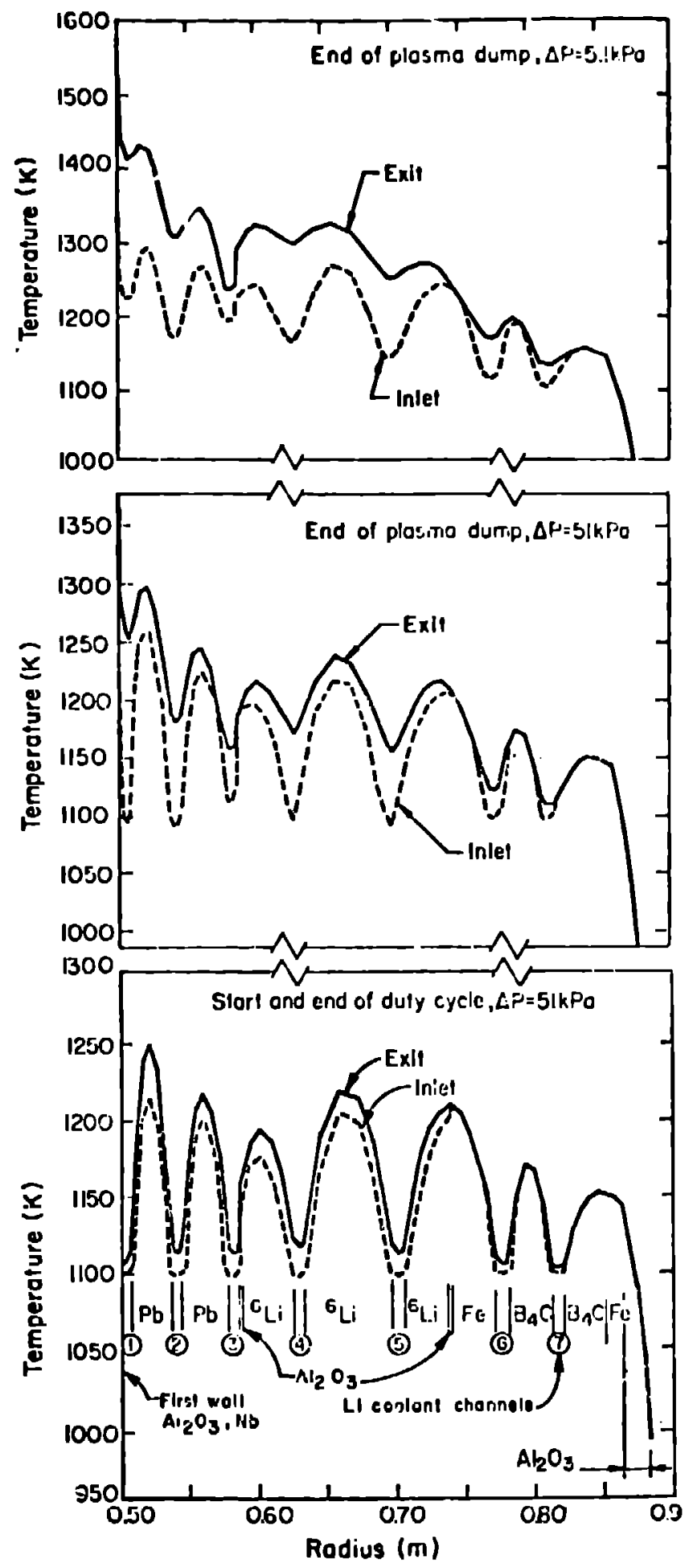

F1g. B Radial temperature distribution at various times during the duty cycle. 